\title{
Characterization and Classification of Romanian Wines by Origin A chemometric approach based on some metals and phenolic composition
}

\begin{abstract}
ROXANA ELENA IONETE, DIANA IONELA STEGARUS*, ELISABETA IRINA GEANA, OANA ROMINA BOTORAN, CLAUDIA SANDRU, MARIUS GHEORGHE MIRICIOIU*

National Research and Development Institute for Cryogenics and Isotopic Technologies - ICSI Rm. Valcea, 4 Uzinei Str., 240050,

Rm. Valcea, Romania

There is a growing trend in food industry in combining safety and quality attributes of products with their distinct regional identity. In thisstudywe used data on several elements ( $\mathrm{Cd}, \mathrm{Cu}, \mathrm{Cr}, \mathrm{Zn}, \mathrm{Pb}$ and Ni) and phenolic compounds (gallic acid, syringic acid, p-coumaric acid, (+)-catechin, (-)-epicatechin, trans-resveratrol, rutin, quercetin and vanillin) as complementary markers in the attempt to characterise and differentiate wines from three winegrowing areas (Murfatlar, Recas and J idvei) of Romania, according to theirgeographical and varietal origin. Wines from south-eastem region (Murfatlar) were characterized by their lower content in $\mathrm{Cu}$, Crand Ni, compared with wines from western (Recas) and central (Jidvei) region, while the content of phenolic compounds in the wine samples showed a visible variation, depending both of the grape variety and geographical origin. The statistical processing tools applied to our results allowed robust diûerentiation between regions, wine varieties, and vintage year. The phenolic compounds (gallic acid, (+)-catechin, (-)-epicatechin, rutin, quercetin and resveratrol) showed the best correlations for the varietal discrimination of wines. Using discriminant analysis, a correctclassification of the wines by variety was achieved in proportion of $88.89 \%$ (based only by phenolic compounds) and $92.59 \%$ (based both on phenolic compounds and metals), revealing that the content of $\mathrm{Cu}, \mathrm{Cr}$ and $\mathrm{Ni}$ is significant for discrimination. Moreover, a 100\% successful classification of wines by region of origin was accomplished.
\end{abstract}

Keywords: phenolic compounds, elemental composition, wine, FAAS, HPLC

The guaranteed quality (e.g. taste, texture, flavor, etc.) of many foodstuffs, including wine, is owed to the specific conditions encountered in the cultivation area. The local characteristics of climate and soil combine to produce crops with certain specific features. Sometimes, people are tempted to confer the consumption of products, mainly forcertain foods such as wine, an aura of romance and tradition, reason for many consumers to demand for a guarantee of the productin terms of naturalness and authenticity.

Wine is a complex matrix which contains many classes of compounds such as sugars, alcohols, acids, flavonoids (tannins), non-flavonoids, minerals and proteins among others. Its composition and distinctive character are basically the result of interactions between several factors, including soil, climate, and environment, grape varieties, and local viticulture practices $[1,2]$.

Therefore, a thorough investigation of the wine regarding its chemical composition can provide essential information for both authentication and quality certification, but also data concerning the vintage year and area of origin [3].

Stable isotopes are primary origin markers used to authenticate wines [4], both in terms of geographic $[5,6]$ and variety [7] differentiation. Combined with other suitable indicators, as organic compounds [8], a better classification and assessment of origin may be provided. However, the possibility to distinguish between near small regions of appellation remains a challenging issue.

When considering the discrimination of the geographical origin of wine and wine authentication, another valuable tool for verifying the origin has been proved to be the quantification of trace elements in wine [9-12] and some metals isotope ratio, such as ${ }^{87} \mathrm{Sr} /{ }^{86} \mathrm{Sr}$ [13-15].

The recent research studies revealed the existence of a good correlation between the content of cations ( $\mathrm{Zn}, \mathrm{W}, \mathrm{Mn}$,
$\mathrm{Fe}, \mathrm{Mg}, \mathrm{Cu}, \mathrm{Ca}, \mathrm{Al}, \mathrm{Sr}, \mathrm{B}, \mathrm{Na}, \mathrm{K}$ ) in wines with the ones in soils from the area/vineyard of origin [16]. Basically, the multielemental composition of wine will reflect the geochemistry of provenience soil. However, there are several factors such as environmental contamination, agricultural practices, climate change or the winemaking processes that can significantly affect the multi-element composition of wines, endangering thus the direct correlation between the soil and wine composition. Asa result, the applicability of multi-element analysis of the wine as fingerprinting technique could be narrowed only for characterization of those high-quality monovarietal wines for which the influence of winemaking processes against wine pattern has been studied previously and is permanenty controlled. In Romania, a multielemental analysis performed on benchmark wines originated from three major regions producing wine (Dobrogea, Moldova and Valea Calugareasca) highlighted that the elements $\mathrm{Mn}, \mathrm{Cr}, \mathrm{Sr}, \mathrm{Ag}$ and Co can be useful indicators for differentiating region of origin [12].

Wines were also classified based on the phenolic compounds $[17,18]$ which are significant secondary metabolites of plants concentrated in the husks, seeds and pulp of beans grape and wine extracts $[2,19]$ contributing to the formation of specific characteristics of wine such as colour, aroma, mouth-feel (astringency) and flavour, the most abundant and functional polyphenols being flavan-3-ol monomers, -catechin and (-)-epicatechin. [20]. These compounds are responsible for different wine types [21]. The structure of these compounds differs depending on the fraction of the grape, through their mean degree of polymerization. [20].

In the attempt to find reliable methods of authentication, several other possibilities to differentiate wines were provided over time, based on the aromatic compounds [21, 22], amino acids, combinations between trace elements and stable

* email: diana.stegarus@icsi.ro, Phone: (+40)746916354; marius.miricioiu@icsi.ro, Phone: (+40)746916354

REV.CHIM.(Bucharest) 70 No. $11 \diamond 2019 \quad$ http://www.revistadechimie.ro 
isotopes or elemental composition and phenolic compounds [23].

The main goal of this work was to assess the usefulness of common investigated parameters for wine characterisation, like metals and phenolics, in classifying and differentiating wines in terms of their geographical and variety origin. Thus, a characterisation of three selected wine types from three differentrenowned wine-growing areas (Murfattar, Recas and Jidvei) of Romania was performed based on data regarding several elements and phenolic compounds. For an accurate classification of the samples, the data were modelled by chemometrics.

\section{Experimental part}

Materials and methods

Samples

Twenty-seven samples of wine (crops 2010, 2011 and 2012) obtained from grapes of three different Vitis vinifera varieties, Chardonnay, Muscat Ottonel and Pinot Noir, grown in Murfatlar (Dobrogea region, south-eastem Romania), Recas (Banat region, western Romania) and Jidvei (TarnaveTransylvania region, central Romania) vineyards were used in our work. In the experimental investigation, for each type of wine were selected samples from each vineyard and vintage year. Samples obtained directly from wineries were collected in $750 \mathrm{~mL}$ glass bottles and stored prior to analysis at $15^{\circ} \mathrm{C}$ and protected from light. All the wine samples were analyzed in two replications.

\section{Characterization of the selected vineyards}

Three vineyards situated in the central, western and southeastern regions of Romania were selected for this work, due to their differentiation in climatic conditions and relief variability and diversity. Jidvei vineyard lies on the gentle hills of southern Transylvania, on the Tarnave's Valley, in central Romania. The land of the vineyard with its brown soil and the continental climate, not especially warm, with average temperatures of $+9{ }^{\circ} \mathrm{C}$, favours during the maturation of grapes special conditions for slow oxidation reactions which helps to continuously accumulates sugars and aromas and prevents the accumulation of acids. These natural conditions seem to be especially favourable to the cultivation of white grape varieties.

Located in western Romania, the Recas vineyard is situated on top of a hill, with gentle slopes. The climate is temperate continental with slight Mediterranean influences. Here the winters are generally mild, the summers are warm, the autumns are long and the transition from winter temperatures to summer ones is rathersudden. The oenoclimatic conditions in the area are favourably for the production of high quality red wines.

Murfatlar vineyard is situated in the south-eastern part of Romania, on hilly terrains situated between the Danube River and the Black Sea. The continental climate, the sheltering effect of the relief against the cold currents coming from the north-east, and the unique and extremely favourable influence of the Black Sea that results in less aggressive summer heat and less frosty winters, with early springs and late autumns, induce here longer vine vegetation offering thus the perfect microclimate to produce high-quality grapes and wines.

\section{Reagents and standards \\ Unless specified, all the used reagents were of analytical grade.}

Gallic acid, syringic acid, p-coumaric acid, $(+)$ - catechin, (-)-epicatechin, trans-resveratrol, rutin, quercetin and vanillin were purchased from Sigma-Aldrich (Steinheim, Germany). Stock solutions of all these standards were prepared in methanol. Working standards were made by diluting the stock solutions with mixture methanol: water $(50: 50, \mathrm{v} / \mathrm{v})$. The linearity of the method was between $0-50 \mathrm{mg} / \mathrm{L}$, for each compound. Both stock and workingstandards were stored at $4^{\circ} \mathrm{C}$ until further use. Formic acid, acetonitrile and methanol were of LC grade, purchased from Merck. (Darmstadt, Germany). Twice distilled and demineralised water produced by a Milli-Q Millipore system (Bedford, MA, USA) was used for preparation of the aqueous solutions.

A multi-element standard solution XVI CertiPUR (mixture of 21 elements in diluted nitric acid), with a certified value of $100 \pm 3 \mathrm{mg} / \mathrm{L}$, purchased from Merck (Darmstadt, Germany) was used for calibration curve in the quantitative analysis of metals ( $\mathrm{Cd}, \mathrm{Cu}, \mathrm{Cr}, \mathrm{Zn}, \mathrm{Pb}$ and $\mathrm{Ni}$ ). Solutions of varying concentrations were prepared for all the metals by diluting the standard solution. Nitric acid $65 \%$ from Merck and ultrapure water, with a maximum resistivity of $18.2 \mathrm{M} \Omega / \mathrm{cm}$, obtained from a Milli-Q Millipore water purification system (Bedford, MA, USA), were used for sample treatment and dilution.

\section{Phenolic compounds}

Phenolic compounds were evaluated by reversed phase high performance liquid chromatography (RP-HPLC) with direct injection. Chromatographic analysis was carried out with a Thermo Finnigan Surveyor Plus HPLC (Thermo Scientific, USA) equipped with a Surveyor Photodiode Array Detector (PDA), Surveyor autosampler, Surveyor LC Pump (Quaternary gradient) and Chrome Quest Chromatography Workstation.

Separation of phenolic compounds was carried out at 30 ${ }^{\circ} \mathrm{C}[19]$, on an Accuacore PFP $(2.6 \mu \mathrm{m}, 100 \times 2.1 \mathrm{~mm})$ column. The flow rate was $0.4 \mathrm{ml} / \mathrm{min}$ and injection volume $1 \mu \mathrm{L}$. Gradientelution of two solvents was used: solvent $A$ consisted of water with $0.1 \%$ formic acid and solventB: acetonitrile with

\begin{tabular}{|c|c|c|}
\hline Time (minutes) & $\mathrm{A} \%$ & $\mathrm{~B} \%$ \\
\hline initial & 98 & 2 \\
\hline $30^{-}$ & $70^{-}$ & $30^{--}$ \\
\hline $35^{-}$ & $25^{-}$ & $75^{-}$ \\
\hline $50^{-}$ & $98^{-}$ & 2 \\
\hline
\end{tabular}

Table 1

SOLVENT GRADIENT CONDITIONS WITH LINEAR GRADIENT

$0.1 \%$ formic acid. The used gradient programme is given in Table 1. Detection was made at $280 \mathrm{~nm}$.

The wines were injected into HPLC system after filtering through a $0.45 \mu \mathrm{m}$ pour size membrane filter. The amount of phenolic compounds in the extracts were calculated as $\mathrm{mg} /$ $L$ wine using external calibration curves, which were obtained for each phenolic standard. Each determination was carried out in duplicate and the mean value was reported. Blank solution and control samples were analyzed in order to monitor performance related to variable factors or random error.

\section{Metals}

A series of six elements ( $\mathrm{Cu}, \mathrm{Zn}, \mathrm{Pb}, \mathrm{Ni}, \mathrm{Cd}$ and $\mathrm{Cr}$ ) were determined in wine samples according to the OIV official methods [24], using a novAA 300 (Analytic Jena, Germany) flame atomic absorption spectrophotometer, equipped with deuterium ark background corrector, in an air-acetylene flame (for $\mathrm{Cu}$ ) and respectivelya Zeenit650 (Analytic Jena, Germany) atomic absorption spectrophotometer equipped with a tubetype pyrolytic graphite furnace. The light sources were hollow cathode lamps from Analytik Jena. Hollow cathode lamps (AnalytikJ ena, Germany) were used as radiation sources, and the analytical measurements were based on time average 
absorbance. The analytical lines: 324.8, 213.9, 283.3, 232, 228.8 and $357.9 \mathrm{~nm}$ were used for registration of integral atomic absorbance values of $\mathrm{Cu}, \mathrm{Zn}, \mathrm{Pb}, \mathrm{Ni}, \mathrm{Cd}$ and $\mathrm{Cr}$, respectively.

Previously, due to the high content of organic compounds in wine, the samples have undergone a pre-treatment procedure, a microwave assisted digestion, using a Mars 5 Microwave (CEM Microwave Technology Ltd, UK) system operated atmax $1600 \mathrm{~W}$ and equipped with fiber optic sensor for automatic temperature control and pressure sensor. Thus, the wine samples $(2.5 \mathrm{~mL}$ ) were introduced in Teflon digestion vessels, followed by addition of $2.5 \mathrm{~mL}$ of concentrated nitric acid. After sealing, the vessels were placed in the microwave oven set to run the following program: step 1-20 min to reach $180^{\circ} \mathrm{C}$ and step 2 - 15 min cooling. After cooling to ambient temperature, the reactors were opened and sonicated to eliminate the nitrous vapors. The resultant solution $(5 \mathrm{~mL})$ was quantitatively transferred into a $50-\mathrm{mL}$ volumetric flask and brought to the volume with ultrapure water.

Each sample was analyzed in duplicate, and each analysis was repeated five times. Calibration standards were prepared from multi-element standard solution XVI CertiPUR.

\section{Data analysis}

Considering the various factors (e.g. geographical origin, vine variety, vintage year and thus climatic conditions, and winemaking) that could influence the composition in metals and the phenolic profile of wine, a factorial analysis was applied to the obtained results for a better understanding of the studied variables considered the mostappropriate to characterize and differentiate the wine samples. All the mathematical and statistical calculations (mean, standard deviation, median, range of variation) were performed using MicrosoftExcel 2010 and XLSTAT software.

\section{Results and discussions}

The experimental results (minimum, maximum and average values) obtained for the analyzed wine samples are detailed further, for both metals and phenolic compounds, grouped by region of origin (vineyard) and wine variety.

Metals concentration
The results for metals measurement shown in Table 2 reveal that in some cases $\mathrm{Cd}$ and $\mathrm{Pb}$ concentration remained below the quantification limitand could not be detected.

A comparative assessment of the abundance of elements in wine according with the region of origin was performed; their tendency of breakdown is as follows:

for Murfattar area: $\quad \mathrm{Cd}<\mathrm{Pb}<\mathrm{Ni}<\mathrm{Cr}<\mathrm{Cu}<\mathrm{Zn}$

for Jidvei and Recas areas: $\mathrm{Cd}<\mathrm{Pb}<\mathrm{Ni}<\mathrm{Cr}<\mathrm{Zn}<\mathrm{Cu}$

If the variety of wines is the comparing term, then the trend is:

forChardonnay:

for Muscat Ottonel:

$\mathrm{Cd}<\mathrm{Pb}<\mathrm{Ni}<\mathrm{Cr}<\mathrm{Zn}<\mathrm{Cu}$

for PinotNoir:

$\mathrm{Cd}<\mathrm{Cr}<\mathrm{Pb}<\mathrm{Ni}<\mathrm{Zn}<\mathrm{Cu}$

$\mathrm{Cd}<\mathrm{Pb}<\mathrm{Ni}<\mathrm{Zn}<\mathrm{Cr}<\mathrm{Cu}$

This classification is specific to this study not being generalized since the concentrations of elements in wine are influenced by several factors including among others the area of origin, type of soil, grape variety, climate (terroir) and wine and oenological practices. That is why the content of an element in wine could be detected in a wide range of values, even if it was made from the same grape variety, which can be observed in Figure 1.

Another overall observation is thatthe recorded values for $\mathrm{Cu}, \mathrm{Cr}$ and $\mathrm{Zn}$ are lower in wines from Murfatlar ( with average values for all wines of $363.24 \mu \mathrm{g} / \mathrm{L}$ for $\mathrm{Cu}, 101.82 \mu \mathrm{g} / \mathrm{L}$ for $\mathrm{Cr}$ and $722.81 \mu \mathrm{g} / \mathrm{L}$ for $\mathrm{Zn}$ ) compared with that from J idvei (657.33 $\mu \mathrm{g} / \mathrm{L}$ for $\mathrm{Cu}, 250.23 \mu \mathrm{g} / \mathrm{L}$ for $\mathrm{Cr}$ and $892.21 \mu \mathrm{g} / \mathrm{L}$ for $\mathrm{Zn}$ ) and Recas ( $1280.62 \mu \mathrm{g} / \mathrm{L}$ for Cu, $141.44 \mu \mathrm{g} / \mathrm{L}$ for Cr and $833.36 \mu \mathrm{g} /$ $\mathrm{L}$ for $\mathrm{Zn})$.

Copper $(\mathrm{Cu})$, which is both an essential element and potentially toxic (when it is in excess), is normally associated with the use of pesticides and the production process. During the winemaking process, the copper content can vary. It decreases due to the formation of insoluble precipitates or increase as a result of corrosion processes that may affect the equipment used. Variation of Cu content in the analyzed wine samples is relatively high (Figure 1), ranging from $10.19 \mu \mathrm{g} / \mathrm{L}$ to $2733 \mu \mathrm{g} / \mathrm{L}$. It may predominantly originate from the residual accumulation of $\mathrm{Cu}$ in soil due to the old farming practices of using copper sulphate or other copper-based fungicides to control the vine downymildew. The results correspond to those reported in a previous study on Romanian wines from the

\begin{tabular}{|c|c|c|c|c|c|c|c|c|c|c|}
\hline \multirow{2}{*}{\multicolumn{2}{|c|}{$\begin{array}{c}\text { Parameters } \\
(\mu \mathrm{g} / \mathrm{L})\end{array}$}} & \multicolumn{3}{|c|}{ Chardonnay } & \multicolumn{3}{|c|}{ Muscat Ottonel } & \multicolumn{3}{|c|}{ Pinot Noir } \\
\hline & & Murfatlar & Recas & Jidvei & Murfatlar & Recas & Jidvei & Murfatlar & Recas & Jidvei \\
\hline \multirow{4}{*}{$\mathrm{Cd}$} & Min & n.d & 0.78 & 0.64 & 0.53 & 0.77 & 0.02 & n.d & 0.47 & 0.49 \\
\hline & Max & 8.46 & 4.81 & 4.56 & 2.11 & 5.93 & 2.14 & 6.53 & 5.93 & 4.74 \\
\hline & Mean & 3.25 & 2.33 & 2.83 & 1.27 & 3.40 & 0.96 & 2.55 & 2.41 & 2.63 \\
\hline & SD & 4.51 & 2.17 & 1.99 & 0.79 & 2.58 & 1.08 & 3.49 & 3.05 & 2.12 \\
\hline \multirow{4}{*}{$\mathrm{Cu}$} & Min & 10.91 & 1639 & 627.90 & 438.00 & 307.30 & 10.19 & 30.12 & 377.40 & 395.60 \\
\hline & Max & 506.6 & 2733 & 750.60 & 841.20 & 1048.00 & 715.60 & 314.60 & 1894.00 & 1803.00 \\
\hline & Mean & 279.86 & 2111.33 & 672.43 & 599.40 & 685.23 & 338.83 & 210.47 & 1045.30 & 960.73 \\
\hline & SD & 250.97 & 562.08 & 67.91 & 213.29 & 370.58 & 355.16 & 156.81 & 774.30 & 743.50 \\
\hline \multirow{4}{*}{$\mathrm{Cr}$} & Min & 9.02 & 3.03 & 4.06 & 7.01 & 3.41 & n.d & 65.85 & 27.83 & 8.91 \\
\hline & Max & 35.25 & 14.85 & 948.60 & 24.20 & 19.88 & 31.93 & 374.40 & 1062.00 & 1208.00 \\
\hline & Mean & 21 & 8.9 & 323.35 & 16.88 & 12.53 & 18.14 & 267.58 & 402.88 & 409.20 \\
\hline & SD & 13.26 & 5.91 & 541.52 & 8.88 & 8.38 & 14.51 & 174.81 & 572.63 & 691.78 \\
\hline \multirow{4}{*}{$\mathrm{Zn}$} & Min & 402.7 & 938.8 & 798.20 & 433.20 & 839.10 & 345.10 & 356.50 & 309.30 & 378.10 \\
\hline & Max & 1676 & 1608 & 1733.00 & 993.10 & 994.88 & 1043.00 & 374.40 & 399.60 & 871.60 \\
\hline & Mean & 1032.23 & 1209.93 & 1195.07 & 773.63 & 927.73 & 809.37 & 362.57 & 362.43 & 672.20 \\
\hline & SD & 636.77 & 352.19 & 483.10 & 29891 & 80.08 & 402.07 & 10.25 & 47.22 & 260.02 \\
\hline \multirow{4}{*}{$\mathrm{Pb}$} & Min & 56.58 & n.d. & n.d. & 8.75 & n.d. & 59.69 & n.d. & 7.93 & 65.07 \\
\hline & $\operatorname{Max}$ & 66.1 & 3.06 & 66.81 & 56.58 & 21.01 & 66.83 & 1.24 & 76.64 & 66.23 \\
\hline & Mean & 61.94 & 2.12 & 44.57 & 37.85 & 14.39 & 64.12 & 1.09 & 38.89 & 65.66 \\
\hline & SD & 4.87 & 0.91 & 37.53 & 25.55 & 11.39 & 3.87 & 0.26 & 34.86 & 0.58 \\
\hline \multirow{4}{*}{$\mathrm{Ni}$} & Min & 50.1 & 75.26 & 33.91 & 43.21 & 20.40 & 41.10 & 77.53 & 90.12 & 65.56 \\
\hline & Max & 83.11 & 92.63 & 63.63 & 64.82 & 54.94 & 126.90 & 97.46 & 103.00 & 105.90 \\
\hline & Mean & 68.38 & 85.34 & 50.81 & 50.53 & 41.43 & 77.80 & 90.51 & 97.44 & 81.87 \\
\hline & SD & 16.79 & 9.02 & 15.28 & 12.38 & 18.46 & 44.22 & 11.25 & 6.62 & 21.25 \\
\hline
\end{tabular}

Table 2

HEAVY METAL CONTENT OF WINE BY TYPE AND REGION 

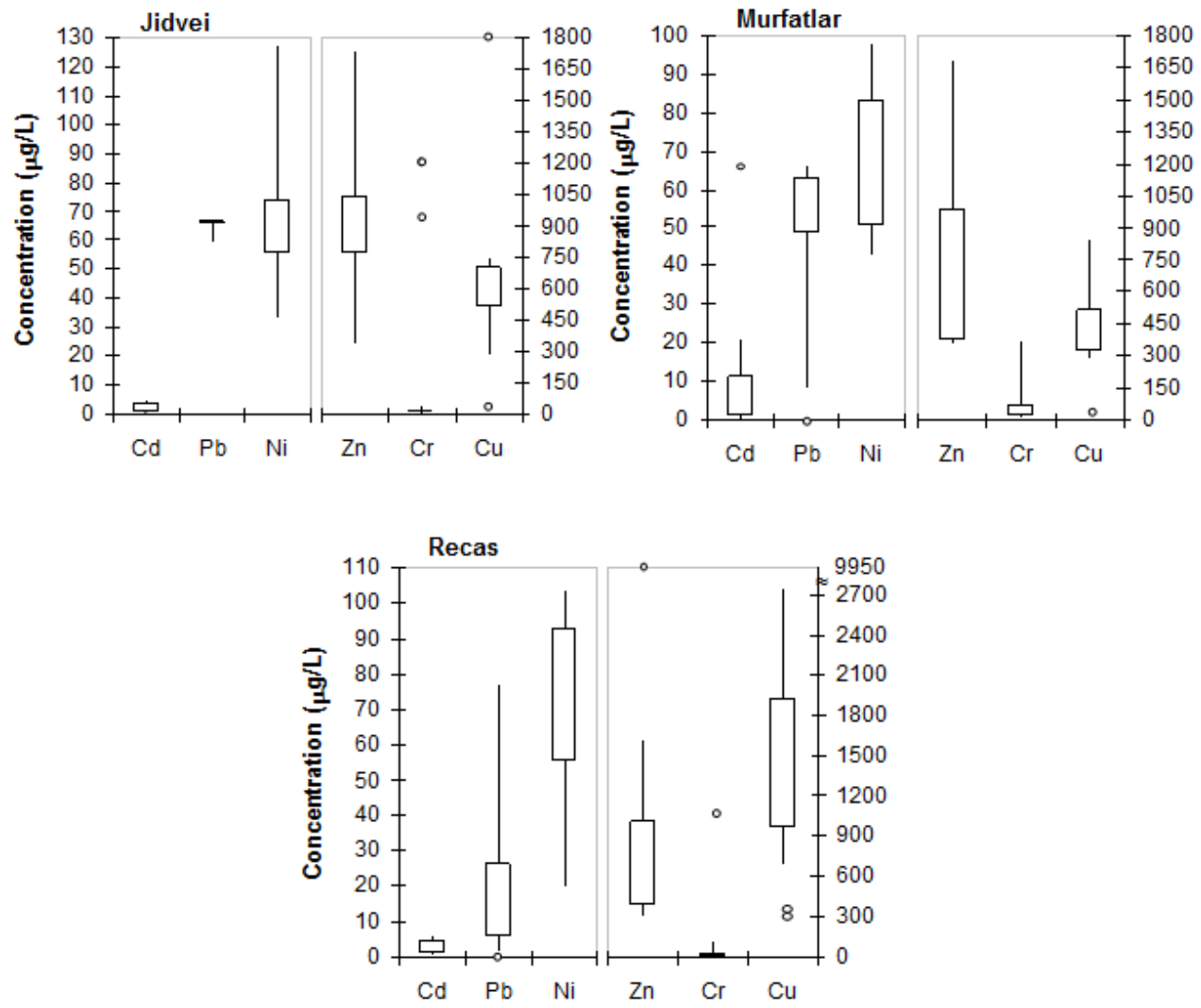

Fig. 1. The global representation of the metals concentrations $(\mu \mathrm{g} / \mathrm{L})$ in wines produced in the three wine regions considered to this study

regions Dobrogea/Murfattar, Muntenia/Valea Calugareasca and Moldova [12].

Regarding the content of zinc ( $\mathrm{Zn}$ ) in wine, it can be also related with the antifungal treatments of the vine. In all the analyzed samples, its variation was between $309.30 \mu \mathrm{g} / \mathrm{L}$ and $1733 \mu \mathrm{g} / \mathrm{L}$, respectively with an average of $816.13 \mu \mathrm{g} / \mathrm{L}$. White wines had higher concentrations of $\mathrm{Zn}$ than red wine, the registered mean values ranging from $1145.74 \mu \mathrm{g} / \mathrm{L}$ for Chardonnay and $836.91 \mu \mathrm{g} / \mathrm{L}$ for Muscat Ottonel, to 465.73 $\mu \mathrm{g} / \mathrm{L}$ for Pinot Noir. All the samples considered in this study had lower values for $\mathrm{Zn}$ than the maximum acceptable imposed by the OIV, of $5 \mathrm{mg} / \mathrm{L}$.

For chromium ( $\mathrm{Cr}$ ), the lowest values were recorded in Muscat Ottonel (mean value $15.85 \mu \mathrm{g} / \mathrm{L}$ ), compared to Chardonnay (117.75 $\mu \mathrm{g} / \mathrm{L}$ ) and Pinot Noir (359.89 $\mu \mathrm{g} / \mathrm{L})$. Also, lowest levels of $\mathrm{Cr}$ were found in wines from Murfatlar and Recas vineyards, with mean value of $101.82 \mu \mathrm{g} / \mathrm{L}$ and 141.44 $\mu \mathrm{g} / \mathrm{L}$ respectively, towards wines from Tarnave - I idvei (mean value $250.23 \mu \mathrm{g} / \mathrm{L}$ ). The wine storage conditions could influence the chromium content. Other possible causes of differences in wine chromium levels are related with the soil elemental composition [25], wine varieties and winemaking.

Regardless of the area or variety, the Pb content in the analyzed samples was lower than that imposed by the OIV (2011), below $0.15 \mathrm{mg} / \mathrm{L}$. The wines from Recas region were characterised by low levels of $\mathrm{Pb}$ (mean value $18.46 \mu \mathrm{g} / \mathrm{L}$ ), while in Murfatlar and J idvei they registered mean values of $33.63 \mu \mathrm{g} / \mathrm{L}$ and $58.12 \mu \mathrm{g} / \mathrm{L}$, respectively.

Nickel is one of the elements which can especially result from the stainless-steel containers. The mean value recorded for Ni in wines from Murfatlar was $69.81 \mu \mathrm{g} / \mathrm{L}$, less than that for wines from J idvei and Recas, of $70.16 \mu \mathrm{g} / \mathrm{L}$, respectively $74.74 \mu \mathrm{g} / \mathrm{L}$. Reported to the variety, the Ni content registered slightly lower values in white wines, from $33.91 \mu \mathrm{g} / \mathrm{L}$ to 92.63 $\mu \mathrm{g} / \mathrm{L}$ and a mean value of $68.18 \mu \mathrm{g} / \mathrm{L}$ for Chardonnay and between $20.4 \mu \mathrm{g} / \mathrm{L}$ and $126.9 \mu \mathrm{g} / \mathrm{L}$, with a mean of $56.59 \mu \mathrm{g} /$ L for Muscat Ottonel, compared to Pinot Noir that registered values from $65.56 \mu \mathrm{g} / \mathrm{L}$ to $105.9 \mu \mathrm{g} / \mathrm{L}$ (mean value $89.94 \mu \mathrm{g}$ / L).
Cadmium is one of the natural components of the wine derived directly from the grapes, the maximum OIV admitted values being of $10 \mu \mathrm{g} / \mathrm{L}$. In large quantities, it is harmful for the human body, affecting the calcium in the bone structure and the kidneys. In ourstudy, for Chardonnaythe Cd content ranged from $8.46 \mu \mathrm{g} / \mathrm{L}$ to n.d. (not detected), with a mean value of $2.80 \mu \mathrm{g} / \mathrm{L}$ and for Muscat Ottonel from $5.93 \mu \mathrm{g} / \mathrm{L}$ to $0.02 \mu \mathrm{g} / \mathrm{L}$ (mean value $1.88 \mu \mathrm{g} / \mathrm{L}$ ), while Pinot Noir had values from 6.53 $\mu \mathrm{g} / \mathrm{L}$ to n.d., with a mean value of $2.53 \mu \mathrm{g} / \mathrm{L}$.

All our results were in agreement with the literature, no significant difference being observed [1, 12, 25].

\section{Phenolic compounds}

The content of phenolic compounds in the wine samples showed a visible variation, depending both of grape variety and geographical origin (Table 3). The main phenolic constituents identified in the wine samples were the syringic acid (average value of $13.02 \mathrm{mg} / \mathrm{L}$ ) as phenolic acid and quercetin (mean $2.12 \mathrm{mg} / \mathrm{L}$ ) and rutin or quercetin-3-0rutinoside (mean $2.09 \mathrm{mg} / \mathrm{L}$ ) as flavonoids. However, quercetin and rutin were predominant in the red wine, Pinot Noir, registering values from $2.43 \mathrm{mg} / \mathrm{L}$ to $11.15 \mathrm{mg} / \mathrm{L}$ for rutin, with an average value of $5.60 \mathrm{mg} / \mathrm{L}$, respectively between $4.39 \mathrm{mg} / \mathrm{L}$ and $8.80 \mathrm{mg} / \mathrm{L}$ for quercitin (average value of 6.27 $\mathrm{mg} / \mathrm{L}$ ). In white wines the content of quercitin and rutin was verylow, the quercitin recording values from n.d. to $0.06 \mathrm{mg} /$ $L$ in Chardonnay and $0.01 \mathrm{mg} / \mathrm{L}$ and $0.25 \mathrm{mg} / \mathrm{L}$ in Muscat Ottonel, while for rutin the values were from n.d. to $0.78 \mathrm{mg} /$ $\mathrm{L}$ for Chardonnay and between $0.13 \mathrm{mg} / \mathrm{L}$ and $1.07 \mathrm{mg} / \mathrm{L}$ for Muscat Ottonel.

Another importantflavonoid, the (+)-catechin, has recorded values between $0.14 \mathrm{mg} / \mathrm{L}$ and $5.33 \mathrm{mg} / \mathrm{L}$, with an average of $1.79 \mathrm{mg} / \mathrm{L}$. A significantly higher content of (+)-catechin was found in the red wine, Pinot Noir (from $2.07 \mathrm{mg} / \mathrm{L}$ to $5.33 \mathrm{mg} /$ $\mathrm{L}$, with an average of $3.45 \mathrm{mg} / \mathrm{L}$ ), compared to the white ones (from $0.14 \mathrm{mg} / \mathrm{L}$ to $2.47 \mathrm{mg} / \mathrm{L}$ and a mean of $1.20 \mathrm{mg} / \mathrm{L}$ for Chardonnay and between $0.71 \mathrm{mg} / \mathrm{L}$ and $1.22 \mathrm{mg} / \mathrm{L}$, averaging $0.72 \mathrm{mg} / \mathrm{L}$ for Muscat Ottonel). In terms of geographical origin, 
the Pinot Noir red wines produced to I idvei averaged a higher content of (+)-catechin, of $4.03 \mathrm{mg} / \mathrm{L}$, compared with those from Murfatlar ( $3.42 \mathrm{mg} / \mathrm{L})$ and, respectively Recas $(2.81 \mathrm{mg} /$ L).

The content of $(+)$-epicatechin is found in significantly higher amounts in Pinot Noir, with values between $1.13 \mathrm{mg} /$ $L$ and $5.27 \mathrm{mg} / \mathrm{L}$, with an average of $2.97 \mathrm{mg} / \mathrm{L}$. The average values recorded for PinotNoir produced in the areas Murfatlar $(3.37 \mathrm{mg} / \mathrm{L})$ and Jidvei $(3.44 \mathrm{mg} / \mathrm{L})$, are higher than those from Recas (2.81 mg/L). For white wines, (+)-epicatechin had values from n.d. to $3.43 \mathrm{mg} / \mathrm{L}$ forChardonnayand between $0.10 \mathrm{mg} / \mathrm{L}$ and $2.02 \mathrm{mg} / \mathrm{L}$ for Muscat Ottonel.

From the category of hydroxybenzoic acids the syringic acid and gallic acid were analyzed. The registered values for syringic acid ranged between n.d. and $39.78 \mathrm{mg} / \mathrm{L}$, with an average of $13.02 \mathrm{mg} / \mathrm{L}$. The highest content of syringic acid was found in the varieties Pinot Noir (mean $16.08 \mathrm{mg} / \mathrm{L}$ ) and MuscatOttonel (average 16.20mg/L) than in Chardonnay $(6.78$ $\mathrm{mg} / \mathrm{L}$ ). For Pinot Noir and Muscat Ottonel, the highest values were found in wines from Recas $(23.56 \mathrm{mg} / \mathrm{L}$, respectively $19.43 \mathrm{mg} / \mathrm{L}$ ), followed by those from Murfatlar ( $14.51 \mathrm{mg} / \mathrm{L}$, respectively $17.41 \mathrm{mg} / \mathrm{L}$ ) and Jidvei $(6.15 \mathrm{mg} / \mathrm{L}$ respectively $11.77 \mathrm{mg} / \mathrm{L}$ ). For Chardonnay wines, the highest values were found in wines of Jidvei $(13.32 \mathrm{mg} / \mathrm{L})$ and less in those of Murfatlar ( $6.91 \mathrm{mg} / \mathrm{L}$ ) and Recas (0.09 mg/L).

Gallic acid was predominantlyidentified in all the samples of PinotNoir, with values between $2.62 \mathrm{mg} / \mathrm{L}$ and $5.37 \mathrm{mg} / \mathrm{L}$, with an average of $3.43 \mathrm{mg} / \mathrm{L}$, and only in three samples of Muscat Ottonel (two from Jidvei - vintage years 2011 and 2012; one from Recas - vintage year 2012), with values between $0.04 \mathrm{mg} / \mathrm{L}$ and $1.68 \mathrm{mg} / \mathrm{L}$ and three samples of Chardonnay (two from Murfatlar - vintage years 2011 and 2012; one from J idvei - vintage year 2011), with values from 0.002 $\mathrm{mg} / \mathrm{L}$ to $0.34 \mathrm{mg} / \mathrm{L}$. The results are consistent to other studies on wines from Romania [23] and Croatia [26].

From the hydroxy cinnamic acids, the $p$-coumaric acid was analyzed, which recorded values between n.d. and $2.34 \mathrm{mg} /$ $\mathrm{L}$, in agreement with other previously published data [23]. In the PinotNoir samples, the mean content of $p$-coumaric acid was $0.22 \mathrm{mg} / \mathrm{L}$, while in white wines samples was found only in two samples of Muscat Ottonel from Jidvei, years 2011 and $2013(0.56 \mathrm{mg} / \mathrm{L}$, respectively $2.34 \mathrm{mg} / \mathrm{L})$ and two samples of Chardonnay, one from Recas, year 2013 (0.31 mg/L) and another one from J idvei, year $2012(0.34 \mathrm{mg} / \mathrm{L})$.

Resveratrol, the main stilbene compound from grapes was found in samples of PinotNoir, with values ranging from 0.52 $\mathrm{mg} / \mathrm{L}$ and $1.26 \mathrm{mg} / \mathrm{L}$ (average of $0.87 \mathrm{mg} / \mathrm{L}$ ) and only in one

Table 3

THE EXPERIMENTAL RESULTS REGARDING THE CONTENT OF PHENOLIC COMPOUNDS IN WINE SAMPLES

\begin{tabular}{|c|c|c|c|c|c|c|c|c|c|c|}
\hline \multirow{2}{*}{\multicolumn{2}{|c|}{$\begin{array}{l}\text { Parameters } \\
\text { (mg/L) }\end{array}$}} & \multicolumn{3}{|c|}{ Chardonnay } & \multicolumn{3}{|c|}{ Muscat Ottonel } & \multicolumn{3}{|c|}{ Pinot Noir } \\
\hline & & Murfatlar & Recas & Jidvei & Murfatlar & Recas & Jidvei & Murfatlar & Recas & Jidvei \\
\hline \multicolumn{11}{|c|}{ Hydroxybenzoic acids (HBA) } \\
\hline \multirow{4}{*}{ gallic acid } & Min & n.d. & n.d & n.d. & n.d. & n.d. & n.d. & 2.80 & 2.62 & 3.38 \\
\hline & Max & 0.32 & n.d. & 0.34 & n.d. & 0.04 & 1.68 & 4.11 & 3.16 & 5.37 \\
\hline & Mean & 0.11 & n.d & 0.11 & n.d. & 0.01 & 0.67 & 3.42 & 2.81 & 4.05 \\
\hline & SD & 0.19 & & 0.20 & n.d. & 0.02 & 0.89 & 0.66 & 0.30 & 1.14 \\
\hline \multirow{4}{*}{ syringic acid } & Min & 0.07 & n.d. & n.d. & 11.51 & 0.03 & n.d & 2.15 & 8.89 & 2.40 \\
\hline & $\operatorname{Max}$ & 20.15 & 0.20 & 39.78 & 24.83 & 34.30 & 21.73 & 39.13 & 38.23 & 12.99 \\
\hline & Mean & 6.91 & 0.09 & 13.32 & 17.41 & 19.43 & 11.77 & 14.51 & 27.57 & 6.15 \\
\hline & SD & 11.46 & 0.10 & 22.92 & 6.79 & 17.58 & 10.98 & 21.32 & 16.23 & 5.93 \\
\hline \multicolumn{11}{|c|}{ Hydroxycinnamic acids (HCA) } \\
\hline \multirow{4}{*}{$p$-coumaric acid } & Min & n.d. & n.d. & n.d. & n.d. & n.d. & n.d & 0.29 & n.d. & 0.09 \\
\hline & $\operatorname{Max}$ & n.d & 0.31 & 0.34 & n.d. & n.d. & 2.34 & 0.75 & 0.14 & 0.20 \\
\hline & Mean & n.d. & 0.10 & 0.11 & n.d. & n.d. & 0.97 & 0.45 & 0.07 & 0.13 \\
\hline & SD & & 0.18 & 0.19 & & & 1.22 & 0.26 & 0.07 & 0.06 \\
\hline \multicolumn{11}{|l|}{ Flavonoials } \\
\hline \multirow[t]{4}{*}{ (+)-catechin } & Min & 0.14 & 1.23 & 0.93 & 0.64 & 0.71 & 0.43 & 2.07 & 2.47 & 2.88 \\
\hline & Max & 1.07 & 1.59 & 2.47 & 0.69 & 1.22 & 0.76 & 4.51 & 3.15 & 5.33 \\
\hline & Mean & 0.58 & 1.37 & 1.63 & 0.66 & 0.89 & 0.60 & 3.42 & 2.90 & 4.03 \\
\hline & SD & 0.47 & 0.19 & 0.78 & 0.03 & 0.29 & 0.17 & 1.24 & 0.37 & 1.23 \\
\hline \multirow[t]{4}{*}{ (+)-epicatechin } & Min & 0.24 & n.d & 0.29 & 0.15 & 0.10 & 0.34 & 2.39 & 1.13 & 3.31 \\
\hline & $\operatorname{Max}$ & 3.43 & 0.53 & 0.90 & 0.54 & 2.02 & 0.92 & 5.27 & 2.69 & 3.50 \\
\hline & Mean & 1.41 & 0.34 & 0.53 & 0.37 & 0.82 & 0.60 & 3.37 & 2.10 & 3.44 \\
\hline & SD & 1.76 & 0.30 & 0.33 & 0.20 & 1.04 & 0.30 & 1.64 & 0.85 & 0.11 \\
\hline \multirow[t]{4}{*}{ quercitin } & Min & 0.02 & n.d. & 0.02 & 0.02 & 0.02 & 0.01 & 4.47 & 4.39 & 5.93 \\
\hline & $\operatorname{Max}$ & 0.06 & 0.03 & 0.04 & 0.04 & 0.25 & 0.06 & 7.40 & 6.45 & 8.80 \\
\hline & Mean & 0.03 & 0.02 & 0.03 & 0.03 & 0.10 & 0.03 & 5.72 & 5.32 & 7.78 \\
\hline & SD & 0.02 & 0.02 & 0.01 & 0.01 & 0.13 & 0.03 & 1.51 & 1.04 & 1.60 \\
\hline \multirow[t]{4}{*}{ rutin } & Min & 0.31 & n.d & 0.25 & 0.19 & 0.16 & 0.13 & 4.13 & 2.43 & 4.92 \\
\hline & Max & 0.47 & 0.32 & 0.78 & 0.26 & 1.07 & 0.38 & 11.15 & 4.42 & 6.90 \\
\hline & Mean & 0.37 & 0.2 & 0.45 & 0.23 & 0.49 & 0.24 & 6.90 & 3.74 & 6.15 \\
\hline & SD & 0.09 & 0.17 & 0.28 & 0.04 & 0.51 & 0.13 & 3.74 & 1.14 & 1.08 \\
\hline \multicolumn{11}{|l|}{ Stilbenes } \\
\hline \multirow[t]{4}{*}{ resveratrol } & Min & n.d. & n.d. & n.d. & n.d. & n.d. & n.d. & 0.52 & 0.55 & 0.87 \\
\hline & Max & n.d & 0.4 & n.d & n.d & n.d & n.d & 1.01 & 0.91 & 1.26 \\
\hline & Mean & n.d. & 0.13 & n.d. & n.d & n.d. & n.d. & 0.77 & 0.78 & 1.05 \\
\hline & SD & & 0.23 & & & 4 & 7 & 0.24 & 0.20 & 0.20 \\
\hline \multicolumn{11}{|c|}{ Others (coming from aging the wine in oak barrels) } \\
\hline \multirow[t]{4}{*}{ vanilin } & Min & n.d & n.d & n.d & n.d & n.d & n.d & 0.10 & 0.05 & 0.08 \\
\hline & $\operatorname{Max}$ & 1.23 & 0.23 & 1.01 & 1.01 & 0.33 & n.d. & 0.50 & 0.58 & 0.34 \\
\hline & Mean & 0.41 & 0.08 & 0.34 & 0.34 & 0.11 & n.d. & 0.25 & 0.24 & 0.20 \\
\hline & SD & 0.71 & 0.13 & 0.58 & 0.58 & 0.19 & & 0.22 & 0.29 & 0.13 \\
\hline
\end{tabular}


sample of Chardonnay originated from Recas, year 2013 ( 0.40 $\mathrm{mg} / \mathrm{L}$ ). Resveratrol content of the PinotNoir samples recorded higher values in wines from Jidvei (average of $1.05 \mathrm{mg} / \mathrm{L}$ ) than those from Murfatlar (average $0.77 \mathrm{mg} / \mathrm{L}$ ) and Recas (average $0.71 \mathrm{mg} / \mathrm{L}$ ).

Vanillin is part of those non-flavonoid phenolic compounds not originating directly from grapes. They derive from the process of wine aging in oak barrels. It was found in the Pinot Noir samples (mean $0.23 \mathrm{mg} / \mathrm{L}$ ) and in three samples of Muscat Ottonel, two from Murfatlar, harvest 2011 and 2012 $(0.005 \mathrm{mg} / \mathrm{L}$, respectively $1.006 \mathrm{mg} / \mathrm{L})$ and one from Reca을, harvest $2012(0.33 \mathrm{mg} / \mathrm{L})$ and three samples of Chardonnay, one from Jidvei, harvest 2013 (1.01 g/L), one from Murfatlar, harvest $2012(1.23 \mathrm{mg} / \mathrm{L})$ and one from Recas, harvest 2013 $(0.23 \mathrm{mg} / \mathrm{L})$.

\section{Wines differentiation by variety}

The main factor affecting the phenolic content in wine is the sun exposure of grapes during the growing/maturation season [26]. Moreover, the terroir effect leaves its mark on both the metals contentand the phenolic compounds of wines.

The results achieved in this work highlighted the several variations in wine composition, both due to the grape variety, area of origin and year of harvest. Thus, the discrimination capability of the measurement results was verified by using a multivariate statistical analysis, based on discriminantanalysis. In a first phase the definition of classes was made starting from the grape variety originating the analyzed wines (Figure 2). A very good differentiation was observed for red wine (Pinot Noir) versus white wines (Chardonnay and Muscat Ottonel). When both phenolic compounds and metals are used as discriminant parameters (Figure 2b) an improvement of the discrimination function can be observed.

Efficiency of classification is given by the grading matrix (Table 4). Therefore, the charactenzzation data of a wine sample (considered unknown) are removed in the calculation model and then the origin of that wine is predicted. Chemometric processing tools applied to our data were able to correctly classify the wines by variety in a proportion of $88.89 \%$ (when only the phenolic compounds are used for analysis) and $92.59 \%$ (when both phenolic compounds and metals are used for analysis). The influence of the metals is mainly observed to white wines, Chardonnay variety.

Elemental and phenolics data were also examined according to the variety using one-way ANOVA. The results indicate that the content of gallic acid, (+)-catechin, (-)epicatechin, rutin, quercetin and resveratrol showed the best correlations with the grapes variety of wines origin (Table 5), being significant for differentiation.

Wines differentiation by geographical origin and harvestyear The ability of some elements like $\mathrm{Ni}, \mathrm{Ag}, \mathrm{Cr}, \mathrm{Sr}, \mathrm{Zn}, \mathrm{Cu}, \mathrm{Rb}$, $\mathrm{Mn}, \mathrm{Pb}, \mathrm{Ba}, \mathrm{Li}, \mathrm{Mg}$, and $\mathrm{Na}$ to discriminate the geographical origin of wines was already demonstrated in some studies on Romanian wines $[6,12,23]$. In our work, commonly used parameters for wine characterisation as heavy metals and phenolic compounds were assessed to see their usefulness in providing preliminary information on wines origin.

Based on the elemental contents, the cross-validation technique provided a $100 \%$ percentage of predicted membership according to the wine geographic origin (71.79 $\% \mathrm{~F} 1$ and $28.21 \% \mathrm{~F} 2$ ) (Figure 3a), but the efficiency of classification given by the confusion matrix for samples prediction was low (correctclassification of wines by origin of provenance in proportion of $62.96 \%$ ). A greatimprovement in the correct classification of wine geographical origin (predictive rate of $100 \%$ ) was obtained by combining the elemental profile with the phenolic composition $(82.69 \% \mathrm{Fl}$; $17.31 \%$ F2) (Figure 3). Among the investigated parameters, $\mathrm{Cu}$ and $\mathrm{Pb}$ were identified as the most significant for geographic differentiation of the wines (Figure 4).

Wines originating from Recas region can be well characterized based on parameters like $\mathrm{Cd}, \mathrm{Ni}, \mathrm{Cu}$, and syringic acid, while wines from Murfatlar can be defined bythe content in rutin, epicatechin and vanillin, and wines from Jidvei by
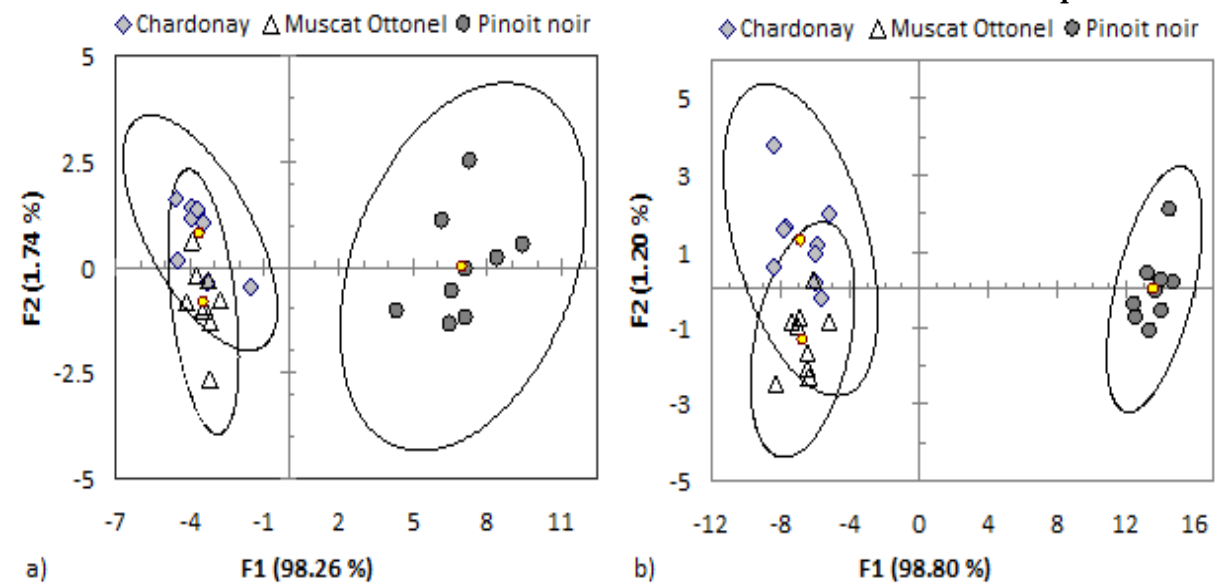

Fig. 2. Differentiation of wines depending on variety by discriminant analysis in terms of

a) phenolic profile and b) phenolic

composition and various heavy metals

a)

F1 $(98.26 \%)$

\begin{tabular}{|c|r|r|r|r|}
\hline & Chardonay & Muscat Ottonel & Pinot noir & $\%$ correct \\
\hline Discriminating elements: phenolic compounds in wines \\
\hline Chardonay & 7 & 2 & 0 & $77.78 \%$ \\
\hline Muscat Ottonel & 1 & 8 & 0 & $88.89 \%$ \\
\hline Pinot noir & 0 & 0 & 9 & $100.00 \%$ \\
\hline Total & 8 & 10 & 9 & $88.89 \%$ \\
\hline Discriminating elements: phenolic compounds and metals in wines & \multicolumn{4}{|c|}{} \\
\hline Chardonay & 8 & 1 & 0 & $88.89 \%$ \\
\hline Muscat Ottonel & 1 & 8 & 0 & $88.89 \%$ \\
\hline Pinot noir & 0 & 0 & 9 & $100.00 \%$ \\
\hline Total & 8 & 10 & 9 & $92.59 \%$ \\
\hline
\end{tabular}




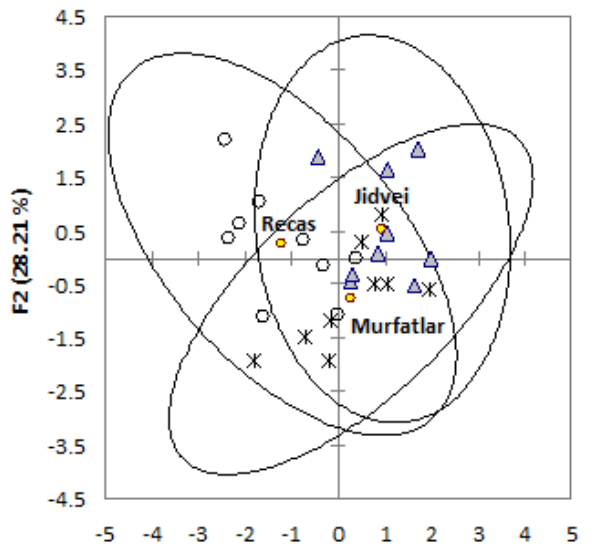

a)

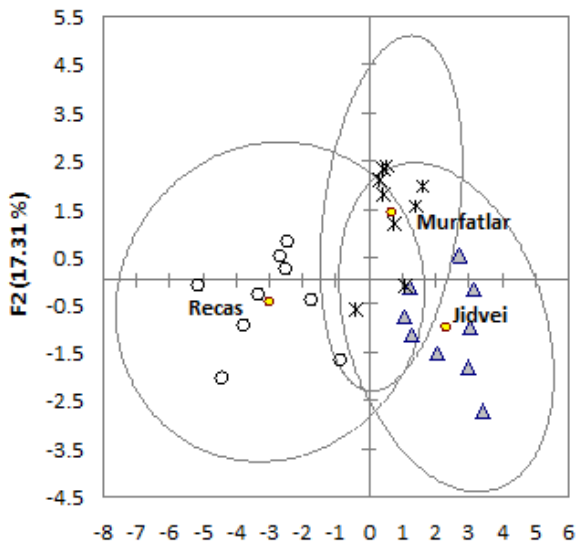

F1 (82.69 \%)
Fig. 3. Differentiation of wines according to geographic origin based on a) the elemental contents and b) the elemental contents and the phenolic composition

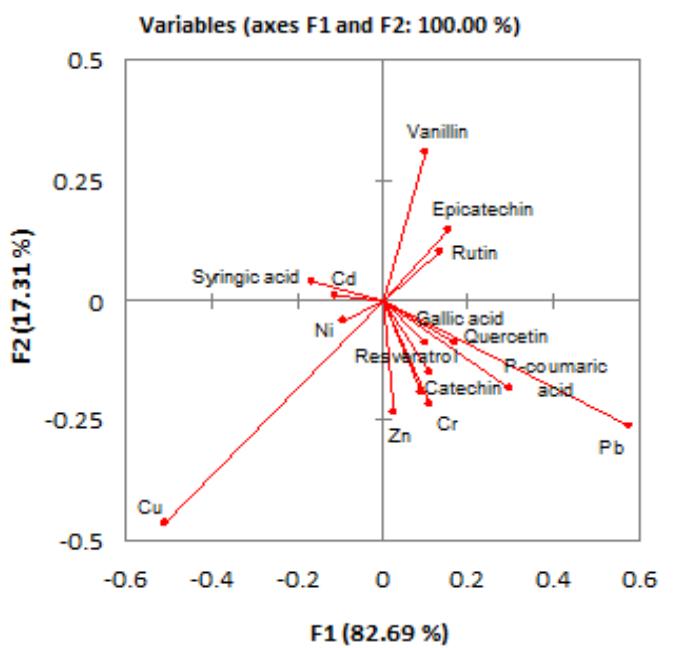

Fig. 4. Correlation between the analyzed parameters and the factors in discriminant analysis of wines geographic origin
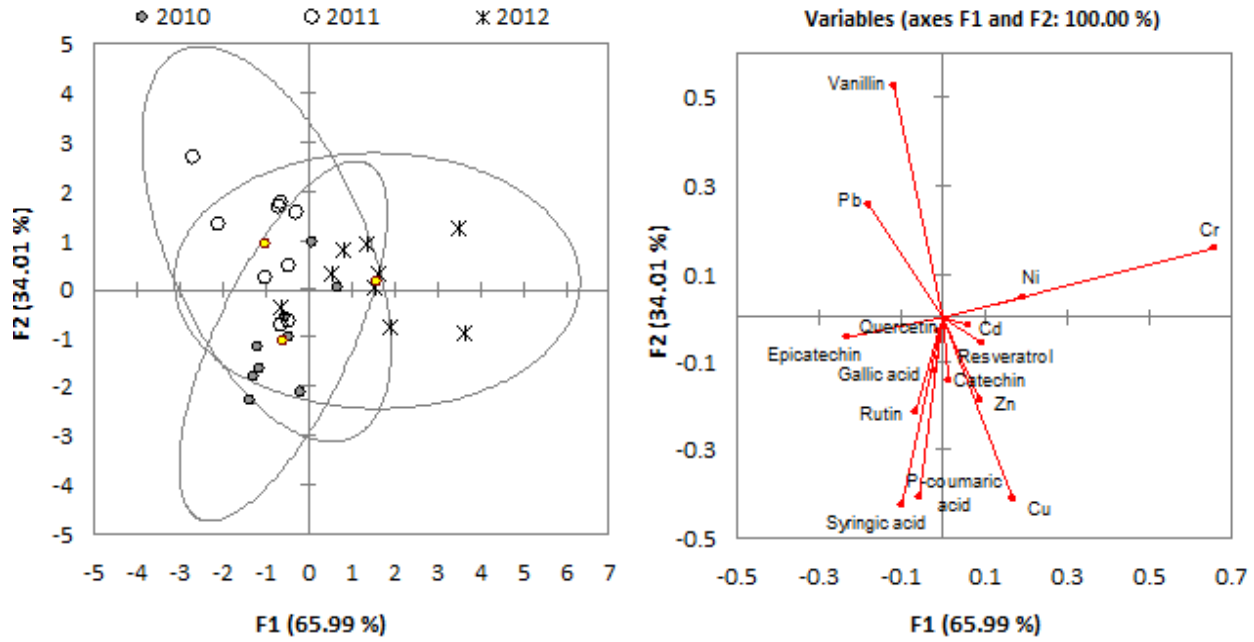

Fig. 5. Correlation chart between the selected variables and the discriminant functions for vintages 2010, 2011 and 2012 parameters like $\mathrm{Zn}, \mathrm{Cr}, \mathrm{Pb}$, resveratrol, catechin, quercitin, gallic acid and $p$-coumaric acid.

The same set of elements that we used to classify the wine samples according to their geographical origin, namely $\mathrm{Cd}, \mathrm{Cu}, \mathrm{Cr}, \mathrm{Zn}, \mathrm{Pb}, \mathrm{Ni}$, gallic acid, (+)-cathechin, syringic acid, vanillin, (-)-epicatechin, $p$-coumaric acid, rutin, resveratrol and quercitin, was applied to discriminate between 2010, 2011 and 2012 vintages. Figure 5 represents the correlation chart of loadings for the selected variables of the stepwise process, in the plane designed by the first two discriminant functions (F1 and F2). Function 1 express $65.99 \%$ of the variance which provides the main separation between the vintage years and has a strong positive correlation with $\mathrm{Cr}$, $\mathrm{Ni}$, and $\mathrm{Cd}$ while function 2 (34.01 \% of the variance) has a strong correlation with syringic acid, $p$-coumaric acid, vanillin and $\mathrm{Pb}$ concentrations. The efficiency of classification provided by the confusion matrix has given a correctprediction proportion of $81.48 \%$.

It was observed that the most useful variables in discriminating vintage 2012 from 2010 and 2011 were $C d, C r$, $\mathrm{Ni}$ and resveratrol, while significant for differentiating wines from 2010 to 2011 were the content of $\mathrm{Cu}, \mathrm{Zn}$, syringic acid, $p$ coumaric acid, rutin and quercitin (Table 6).

Concluding, the set of markers, sixinorganic ( $\mathrm{Cd}, \mathrm{Cu} \mathrm{Cr}, \mathrm{Zn}$, $\mathrm{Pb}$, and $\mathrm{Ni})$ and nine organic $((+)$-catechin, (-)-epicatechin, $p$-coumaric acid, gallic acid, syringic acid, rutin, quercitin, resveratrol and vanillin), thatwe used to characterize the wines, provide us a good classification of the samples in terms of grape varietyand geographical origin, even vintage years. Our results confirm the powerful link between the wine composition and terroir, being in agreementwith those reported by other authors [6, 23]. 


\begin{tabular}{|c|c|c|c|c|c|}
\hline Parameters & Pinoit noir & Chardonay & Muscat Ottonel & $\operatorname{Pr}>F$ & Significant \\
\hline$\overline{\mathrm{Cd}}$ & $2.529 \mathrm{a} \mathrm{a}$ & $2.803 \mathrm{a} \mathrm{a}$ & $1.879 \mathrm{a} \mathrm{a}$ & 0.708 & No \\
\hline $\mathrm{Cu}$ & $738.836 \mathrm{aa}$ & $1021.210 \mathrm{a} \mathrm{a}$ & $541.154 \mathrm{a} a$ & $0.329^{\circ}$ & No \\
\hline $\mathrm{Cr}$ & 359.888 a a & $117.750 \mathrm{a} \mathrm{ab}$ & $15.848 \mathrm{ab}$ & 0.087 & No \\
\hline $\mathrm{Zn}$ & $465.733 \mathrm{bb}$ & $1145.744 \mathrm{a} a$ & $836909 \mathrm{ab}$ & $0.001^{-}$ & Yes \\
\hline $\mathrm{Pb}^{-1}$ & 35.210 a a & $36.210 \mathrm{a} a$ & 38.785 a a & 0.968 & No \\
\hline $\mathrm{Ni}^{-}$ & 89.941 a a & $68.179 \mathrm{abb}$ & $56.587 \mathrm{bb}$ & 0.012 & Yes \\
\hline Gallic acid & $3.429 \mathrm{a} \mathrm{a}$ & $0.076 \mathrm{bb}$ & $0.229 \mathrm{bb}$ & 0.000 & $\mathrm{Yes}$ \\
\hline Catechin & $3.452 \mathrm{a} \mathrm{a}$ & $1.196 \mathrm{bb}$ & $0.717 \mathrm{bb}$ & 0.000 & Yes \\
\hline Syringic acid & $16.076 \mathrm{aa}$ & $6.781 \mathrm{a} a$ & $16.206 \mathrm{a} a$ & 0.289 & No \\
\hline Vamillin & $0.230 \mathrm{a} \mathrm{a}$ & $0.277 \mathrm{a} \mathrm{a}$ & $0.152 \mathrm{a} a$ & 0.763 & No \\
\hline Epicatechin & $2.969 \mathrm{a} \mathrm{a}$ & $0.801 \mathrm{bb}$ & $0.596 \mathrm{bb}$ & $0.000^{\circ}$ & Yes \\
\hline$P$-coumanc acid & $0.229 \mathrm{a} \mathrm{a}$ & $0.135 \mathrm{a} a$ & 0.384 a a & 0.511 & No \\
\hline Rutin & $5.597 \mathrm{a}$ & $0.419 \mathrm{bb}$ & $0.320 \mathrm{bb}$ & $0.000^{\circ}$ & Yes \\
\hline Resveratrol & $0.866 \mathrm{aa}$ & $0.338 \mathrm{bb}$ & $0.330 \mathrm{bb}$ & 0.000 & Yes \\
\hline Quercetin & $6.272 \mathrm{aa}$ & $0.029 \mathrm{bb}$ & $0.052 \mathrm{bb}$ & 0.000 & Yes \\
\hline
\end{tabular}

Table 5

VARIATION OF THE METAL AND PHENOLICS CONTENT OF COLLECTED WINES OF DIFFERENT VARIETY

Means followed by different lowercase letters in the line differ significantib by ANOVA complemented by Tukey's test of multiple comparisons; significance level of $5 \%$, Results expressed in $m g / L$ for phenolic compounas and $\mu g / L$ for metals

\section{Conclusions}

The results of this study report that classical parameters, like phenolic compounds and metals, commonly used for characterization of wines may provide a picture of the oenoclimatic conditions variability across differentregions and years, subsequentlyapplicable to achieve reliable information for classifying wines by variety, origin of provenance and vintage.

By multivariate analysis based on the concentration of six inorganic ( $\mathrm{Cd}, \mathrm{Cu} \mathrm{Cr}, \mathrm{Zn}, \mathrm{Pb}$, and $\mathrm{Ni})$ and nine organic ((+)catechin, (-)-epicatechin, $p$-coumaric acid, gallic acid, syringic acid, rutin, quercitin, resveratrol and vanillin) compounds, it was possible to discriminate wines from three grape varieties (Chardonnay, MuscatOttonel and PinotNoir), obtained in three wine-producing regions of Romania (Recas, Murfatlar and Jidvei) during the production years, 2010, 2011 and 2012.

The content of gallic acid, (+)-catechin, (-)-epicatechin, rutin, quercetin and resveratrol revealed the best ability for discriminating the wine samples according to the grapes variety of origin. By using variance analysis by average comparative (ANOVA) and linear discriminant analysis (LDA) based on the concentration of the selected elements a correct classification of the wines byvariety was achieved in proportion of $88.89 \%$ (based only by phenolic compounds) and $92.59 \%$ (based both on phenolic compounds and metals), revealing that the content of $\mathrm{Cu}, \mathrm{Cr}$ and $\mathrm{Ni}$ is significantfordiscrimination. Moreover, a 100\% successful classification of wines by region of origin was accomplished, while a differentiation by year of production was achieved with a correct prediction rate of $81.48 \%$.

The most important conclusion is the fact that based on wine characterization parameters, like phenolics compounds coupled with multi-element, a separation of wine samples in terms of variety and geographical origin can be achieved.

Acknowledgements The authors thank to Romanian MinistryofEducation and Research, National Authority for Scientific Research for the financial support, under the NUCLEU Program, project PN16 360402 Advanced research on the authentication of food origin for implementing innovative fingerprinting methodologies - Emphasis on fruit-based products.

\section{References}

1.GONZAAVEZ, A., LLORENS, A., CERVERA, M.L., ARMENTA, S., DE LA GUARDIA M., Food Chem., 112, 2009, p. 26.

2.LA TORRE, G.L., SAITTA, M., VILASI, F., PELLICANO, T., DUGO, G., Food Chem., 94, 2006, p. 640.
3. TOPALA L., TATARU D., Rev.Chim.(Bucharest), 69, no. 2, 2018, p. 469473.

4.CHRISTOPH, N., BARATOSSY, G., KUBANOVIC, V., KOZINA, B., ROSSMANN, A., SCHLICHT, C., VOERKELIUS, S., Mitt. Klosterneuburg., 54, 2004, p. 144.

5. OGRINC, N., KOSIR, I.J., KOCJANCIC, M., KIDRIĖ, J., J. Agric. Food Chem., 49, 2001, p. 1432.

6.DINCA, O.R., IONETE, R.E., COSTINEL, D., GEANA, E.I., POPESCU, R., STEFANESCU, I., RADU, G.L., Food Anal. Methods, 9, no. 8, 2016, p. 2406. 7.COSTINEL, D., TUDORACHE, A., IONETE, R.E., VREMERA, R., Anal. Lett., 44, no. 18, 2011, p. 2856.

8.GEANA, E.I., POPESCU, R., COSTINEL, D., DINCA, O.R., IONETE, R.E., STEFANESCU, I., ARTEM, V., BALA, C., Food Chem., 192, 2016, p. 1015.

9.ALMEIDA, C.M., VASCONCELOS, M.T., J. Agric. Food Chem., 51, no. 16, 2003, p. 4788.

10.CASTINEIRAGOMEZ, M.M., BRANDT, R.,J AKUBOWSKI, N., ANDERSSON, T., J. Agric. Food Chem., 52, 2004, p. 2953.

11.COETZEE, P.P., STEFFENS, F.E., EISELEN, R.J., AUGUSTYN, O.P., BALCAEN, L., VANHAECKE, F., J. Agric. Food Chem, 53, 2005, p. 5060.

12.GEANA, E.I., IORDACHE, A.M., IONETE, R.E., MARINESCU, A., RANCA, A., CULEA, M., Food Chem., 138, no. 2-3, 2013, p.1125.

13.MARCHIONNI, S., BRASCHI, E., TOMMASINI, S. et al., J. Agric. Food Chem, 61, 2013, p. 6822.

14.DURANTE, C., BASCHIERI, C., BERTACCHINI, L. et al., Food Chem., 173, 2015, p. 557.

15.GEANA, E.I., SANDRU, C., STANCIU, V., IONETE, R.E., Food Anal. Methods, 10, no. 1, 2017, p. 63.

16. DUTRA, S.V., ADAMI, L., MARCON, A.R., CARNIELI, G.J., ROANI, C.A., SPINELLI, F.R., LEONARDELLI, S., DUCATTO, C., MOREIRA, M.Z., VANDERLINDE, R., Anal. Bioanal. Chem., 401, 2011, p. 1571.

17.GALGANO, F., CARUSO, M., PERRETTI, G., FAVATI, F., Eur. Food Res. Technol., 232, 2011, p. 889.

18. SOTO VÁZQUES, E., RIO SEGADE, S., CORTESDIEGUEZ, S., Int. J. Food Sci. Technol., 46, 2011, p. 542.

19. GEANA, E.I., IONETE, R.E., TUDORACHE, A., PASA, R., POSTOLACHE, E., RANCA, A., Asian J. Chem., 23, no. 12, 2011, p. 5197.

20.MUNCACIU, M., MARIN, F., POP, N., BABES, A., BUNEA, C., BALEA ,S., CALUGAR, A., Rev. Chim.(Bucharest), 69, no. 9, 2018, p. 2372.

21.GREEN, J.A., PARR, W.V., BREITMEYER, J., VALENTIN, D., SHERLOCK, R., Food Res Int, 44, 2011, p. 2788.

22.POPESCU, R., COSTINEL, D., IONETE, R.E., STEGARUS, D.I., MARINESCU A.C., TUDORACHE, A., Rev. Chim. (Bucharest), 62, no. 2, 2014, p. 168.

23.GEANA, E.I., MARINESCU, A., IORDACHE, A.M., SANDRU, C., IONETE, R.E., BALA, C., Food Anal. Methods, 7, 2014, p. 2064.

24. *** OIV, Compendium of international methods of wine and must analysis, 1-2, 2013.

25. DINU, C., UNGUREANU, E., VASILE, G., KIM, L., IONESCU, I., ENE, C., SIMION M., Rev. Chim. (Bucharest), 69, no. 1, 2018, p. 14-20.

26. RASTIJA, V., SRECNIK, G., MEDIC-SARIC, M., Food Chem., 115, 2009, p. 54.

Manuscript received: 22.01.2019 